\title{
Septic pulmonary embolism
}

\author{
Satish Swain (10 , Animesh Ray
}

Department of Medicine, All India Institute of Medical Sciences, New Delhi, India

\section{Correspondence to}

Dr Animesh Ray;

doctoranimeshray@gmail.com

Accepted 17 September 2021

\section{DESCRIPTION}

A 45-year-old man, with poorly controlled diabetes (HbA1c-10.1), presented with fever and gluteal pain for 3 days. On examination, there was a swelling over left gluteal region with induration and an overlying discharging sinus. Ultrasonography of the swelling showed subcutaneous oedema with underlying collection. Incision and drainage was done and the pus was sent for bacteriological, tubercular, fungal stains and culture. Gram stain showed gram positive cocci in clusters and subsequently there was growth of methicillin-resistant Staphylococcus aureus, for which the patient was started on linezolid. Two days later, the patient developed new-onset cough with shortness of breath. A chest radiograph was done which showed bilateral nodular densities with cavitation (figure 1). Subsequently, a high-resolution CT of chest showed multiple cavitating nodules along with feeding vessel sign and bilateral pleural effusion (figure 2). There was no any evidence of peripheral thrombophlebitis. A two-dimensional transthoracic echocardiography was also done, which did not show any evidence of infective endocarditis. With the given radiological picture, a differentials of septic pulmonary emboli (SPE), pulmonary vasculitis, pulmonary infections(tubercular or fungal) and metastatic lesions were kept. Potassium hydroxide $(\mathrm{KOH})$ stain and fungal cultures from respiratory samples were negative. Sputum sent for acid-fast bacilli and GeneXpert was also negative. There was no associated cervical, mediastinal lymphadenopathy or discernible mass. The clinical picture and duration of illness was not suggestive of pulmonary vasculitis and antineutrophilic cytoplasmic antibody was also negative. With the given clinical scenario and imaging findings a final diagnosis of gluteal abscess with SPE was made and the patient was managed

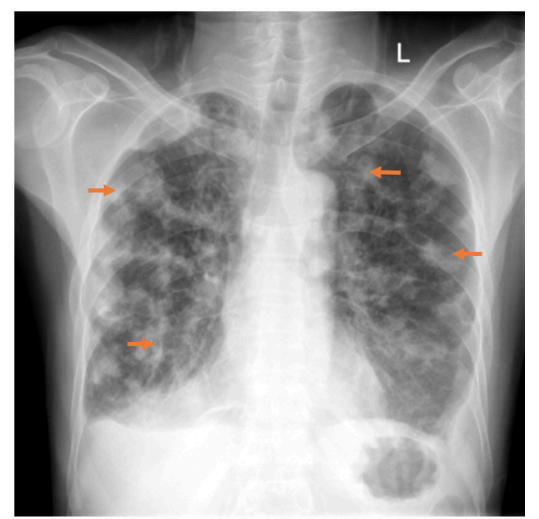

Figure 1 Chest radiograph showing diffuse bilateral nodular densities with cavitation (red arrows).

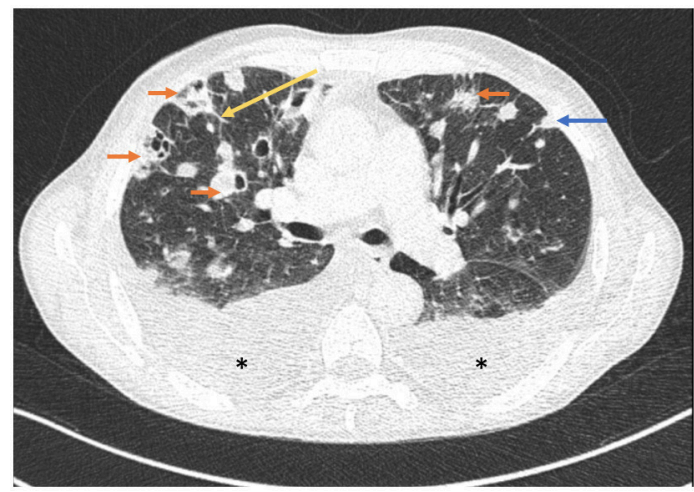

Figure 2 Axial CT images of the patient showing various radiographic features of SPE, bilateral discrete nodules with varying degrees of cavitation (multiple red arrow); subpleural wedge-shaped opacities (blue arrow); feeding vessel sign (yellow arrow) and bilateral pleural effusion ( $*$ marks). SPE, septic pulmonary emboli.

with intravenous antibiotics for 4 weeks to which the patient showed steady improvement.

SPE are caused by embolisation of thrombi containing micro-organisms to pulmonary vascular beds causing infarctions and microabscesses. ${ }^{1}$ Common causes of SPE include infective endocarditis, skin and soft-tissues infection, intravascular catheters, pacemakers, intravenous drug use, dental abscess, septic thrombophlebitis, puerperal sepsis, etc. ${ }^{2-5}$ The characteristic radiological finding on CT scan is bilateral discrete nodules with varying degrees of cavitation; the nodules may differ in size reflecting recurrent embolic showers. ${ }^{6}$ Other findings include subpleural wedge-shaped opacities and feeding vessel sign (a distinct vessel leading directly to a nodule), which is considered to be pathognomic of SPE. ${ }^{7}$ Pleural effusion or empyema may occasionally complicate SPE. Radiological features of SPE can mimic other conditions like pulmonary vasculitis (granulomatosis with polyangiitis), extrathoracic metastasis (commonly squamous cell carcinoma) and pulmonary thromboembolism. ${ }^{8} 9$ The duration as well as clinical manifestations serves as

\section{Learning points}

- In all patient with septic pulmonary embolic, the primary cause must be evaluated and addressed.

- Radiological features of septic pulmonary embolic may mimic other conditions like pulmonary vasculitis, extrathoracic metastasis from head and neck (commonly squamous cell carcinoma) and pulmonary thromboembolism. 
important pointers in the etiological diagnosis of this condition. Rapidly evolving clinical picture with cavity ( $<12$ weeks) is seen in infectious aetiology while chronic or indolent ( $>12$ weeks) duration is more suggestive of malignancy or vasculitis. ${ }^{10} 11$ Finding the underlying cause followed by appropriate treatment is crucial for management.

Contributors SS and AR contributed to the design and writing the manuscript. SS and AR both were involved in patient care.

Funding The authors have not declared a specific grant for this research from any funding agency in the public, commercial or not-for-profit sectors.

Competing interests None declared.

Patient consent for publication Consent obtained directly from patient(s).

Provenance and peer review Not commissioned; externally peer reviewed.

\section{ORCID iDs}

Satish Swain http://orcid.org/0000-0001-9466-3531

Animesh Ray http://orcid.org/0000-0002-9434-5338

\section{REFERENCES}

1 Jorens PG, Van Marck E, Snoeckx A, et al. Nonthrombotic pulmonary embolism. Eur Respir J 2009;34:452-74.
2 Ye R, Zhao L, Wang C, et al. Clinical characteristics of septic pulmonary embolism in adults: a systematic review. Respir Med 2014;108:1-8.

3 Mathew UE, Ray A, Soneja M, et al. Pyomyositis Complicated by Deep Venous Thrombosis - A Unique Case of Reverse Lemierre's Syndrome. J Assoc Physicians India 2017;65:87-91.

4 Talupula RM, Ray A, Manchanda S, et al. Reverse Lemierre's syndrome: a case report. Egypt J Bronchol 2018;12:363-6.

5 Singh AD, Makkar N, Ray A, et al. Phlegmasia cerulea dolens presenting with acute compartment syndrome and pulmonary embolism. BMJ Case Rep 2018;2018. doi:10.1136/bcr-2018-224879. [Epub ahead of print: 13 Jun 2018].

6 Han D, Lee KS, Franquet T, et al. Thrombotic and nonthrombotic pulmonary arterial embolism: spectrum of imaging findings. Radiographics 2003;23:1521-39.

7 Rossi SE, Goodman PC, Franquet T. Nonthrombotic pulmonary emboli. AJR Am J Roentgenol 2000;174:1499-508.

8 Ragesh R, Ray A, Mian A, et al. Cavitary lung lesions in a difficult-to-treat asthma patient. J Assoc Physicians India 2016;64:73-6.

9 S Kumar S, Ray A, Vikram NK, et al. Unusual case of chronic cavitary pulmonary aspergillosis presenting as spontaneous pneumothorax in an immunocompromised man. BMJ Case Rep 2021;14:e241655.

10 Gafoor K, Patel S, Girvin F, et al. Cavitary lung diseases: a clinical-radiologic algorithmic approach. Chest 2018;153:1443-65.

11 Mian A, Singal AK, Bakhshi S, et al. Treatment of pulmonary embolism with chemotherapy in a case of newly diagnosed osteosarcoma. J Assoc Physicians India 2019;67:76-8

Copyright 2021 BMJ Publishing Group. All rights reserved. For permission to reuse any of this content visit https://www.bmj.com/company/products-services/rights-and-licensing/permissions/

BMJ Case Report Fellows may re-use this article for personal use and teaching without any further permission.

Become a Fellow of BMJ Case Reports today and you can:

- Submit as many cases as you like

- Enjoy fast sympathetic peer review and rapid publication of accepted articles

- Access all the published articles

- Re-use any of the published material for personal use and teaching without further permission

Customer Service

If you have any further queries about your subscription, please contact our customer services team on +44 (0) 2071111105 or via email at support@bmj.com.

Visit casereports.bmj.com for more articles like this and to become a Fellow 